Original Research Paper

\title{
Microcystin-LR Affects Ultimobranchial Gland of Catfish Heteropneustes fossilis
}

\author{
Chandra Prakash and Sunil Kumar Srivastav* \\ Department of Zoology, DDU Gorakhpur, University Gorakhpur-273009, U.P., India
}

\author{
Article history \\ Received: 21-11-2020 \\ Revised: 26-02-2021 \\ Accepted: 09-03-2021 \\ Corresponding Author: \\ Sunil Kumar Srivastav \\ Department of Zoology, DDU \\ Gorakhpur, University \\ Gorakhpur- 273009, U.P., India \\ Email: sunilsrivastav@hotmail.com
}

\begin{abstract}
Microcystin-LR (2.5 $\mu \mathrm{g} / 25 \mathrm{~g})$ was injected intraperitoneally to the fish Heteropneustes fossilis on day 1, 10 and $20 \mathrm{kept}$ in either freshwater or freshwater containing $\mathrm{ZnCl}_{2}$. The fishes were killed on day 5, 10, 20 and 30 day. The serum calcium levels was estimated and ultimobranchial glands were processed for routine histology. Microcystin-LR administration to fish Heteropneustes fossilis induced hypocalcemia and ultimobranchial gland exhibit decreased nuclear volume of the ultimobranchial cells. Degenerative ultimobranchial gland cells were obtained after day 20. While the fish injected with MC-LR kept in $\mathrm{ZnCl}_{2}$ has shown no change in serum calcium levels as well as in histology of ultimobranchial gland cells.
\end{abstract}

Keywords: Microcystin-LR, Catfish, Calcium, Hypocalcemia, Ultimobranchial Gland

\section{Introduction}

Cyanobacteria or blue green algae, proliferate in water bodies such as lakes, ponds, reservoirs and slow running streams when nutrients are available and the water is warm. Cyanobacteria, well recognized for their ability to fix atmospheric nitrogen, are the most primitive gram negative, oxygenic photosynthesizer prokaryotes. Several species of cyanobacteria are known to produce toxins, these are microcystins, out of which a few are toxic. Toxic cyanobacteria have been reported from marine, brackish water and freshwater habitat throughout the world (Kumar and Sinha, 2014). The first report regarding toxic cyanobacteria (Nodularia spcimigena) was published by (Francis, 1878), which prompted many workers in several countries to investigate the same. Wide occurrence of toxic cyanobacterial blooms are creating serious problems in freshwater environment (Carmichael, 1992; 1994; Sivonen, 1996; Codd et al., 1999; Tyagi et al., 1999; Nasri et al., 2004; Wiegand and Pflugmacher, 2005).

Two thousand species of cyanobacteria have been reported to occur globally in aquatic habitats which are surviving in wide range of environmental conditions. The production of toxin has been correlated with period of rapid growth (bloom) and 25-70\% blooms are reported as toxic (Rogers et al., 2005). The cell wall of algae burst when it dies, thus the toxins released into the water. Microcystins are extremely stable and resist common chemical breakdown such as oxidation under conditions found in most natural water bodies. Cyanotoxin are chemical substances of a diverse group having different toxicological properties. Several cyanotoxins, produced as bioactive compounds of cyanobacterial origin, have been recognized as priority hazard to human and animal health (Carmichael, 2001; Rao et al., 2002). These cyanotoxins contain three types of neurotoxic alkaloids (anatoxin-a, anatoxin-a (S), saxitoxins), cyclic peptides, which are chiefly hepatotoxic (microcystins and nodularins), hepatotoxic and cytotoxic alkaloid cylindrospermopsin and dermatotoxic compounds from marine cyanobacteria (aplysiatoxins and lyngbyatoxins). Moreover, the integral parts of cell walls of microcystins i.e., lipopolysaccharides cause irritant and pyrogenic effects (Chorus, 2001; Codd et al., 2005).

No study has yet been carried out with respect to Microcystin-LR (MC-LR) toxicity on fish calcium regulating endocrine organ i.e., Ultimobranchial Glands (UBG), that is why it was aimed to study the effect of the toxin released from MC-LR on UBG of catfish $H$. fossilis.

\section{Materials and Methods}

\section{Collection and Acclimatization of Test Animal}

Freshwater catfish Heteropneustes fossilis (both sexes, average body weight 25-35 g) were collected and acclimatized for two weeks in $250 \mathrm{~L}$ plastic pool during the experiment. Small mesh dip net of soft material was used for gentle handling of fish for experiment. Care was taken to minimize stress to the fish. Dead fish were removed immediately. 


\section{Experimental Design}

Microcystin was dissolved in ethanol $(1 \mathrm{~mL})$ and diluted with $0.6 \%$ saline to prepare the stock solution $(100 \mu \mathrm{g} / 50 \mathrm{~mL}) .160$ fish were used in the experiment and divided into four groups each containing 40 fish and employed as follow:

Group A: Fish from this group served as control and were given intraperitoneal injection of $0.6 \%$ saline (vehicle) at the initiation of experiment and on 10 and 20 days

Group B: Fish from this group were intraperitoneally injected with microcystin-LR $(2.5 \mu \mathrm{g} / 25 \mathrm{~g})$ at the initiation of the experiment and on 10 and 20 days

Group C: Fish were treated same as group B and kept in freshwater containing $5 \mathrm{mg} \mathrm{ZnCl} / \mathrm{L}$

Group D: Fish from this group were injected similarly as in group A and kept in freshwater containing $5 \mathrm{mg} \mathrm{ZnCl} / \mathrm{L}$

\section{Biochemical Estimations}

Fish were sacrificed (under slight anesthesia with MS222) from group A, B, C and D after 5, 10, 20 and 30 days after initiation of the experiment. Blood was collected after sectioning of caudal peduncle and sera were separated by centrifugation at 3,500 rpm and analyzed for calcium (calcium kit, RFCL Limited, India) and inorganic phosphate levels (inorganic phosphorous reagent kit, RFCL Limited, India) and expressed as $\mathrm{mg} / 100 \mathrm{~mL}$.

\section{Preparation for Histological Slides}

The area adjoining the heart along with the oesophagus were removed and fixed in aqueous Bouin's fluid.
Tissues were routinely processed in graded series of alcohols, cleared in xylene and embedded in paraffin. Serial sections were cut at $6 \mu \mathrm{m}$.

The ultimobranchial glands were stained with Hematoxylin-Eosin (HE)

\section{Nuclear Volume}

Nuclear indexes (maximum length and maximum width) of ultimobranchial cells were taken with the aid of ocular micrometer and then the nuclear volume was calculated as:

$$
\text { volume }=4 / 3 \pi a b^{2}
$$

where, ' $a$ ' is the major semi axis and ' $b$ ' is the minor semi axis. In the gland, when there are degenerating nuclei, only the indexes of intact nuclei were measured.

\section{Statistical Analysis}

All data were presented as the mean $\pm \mathrm{SE}$ of six specimens and Student's $t$ test was used for the determination of statistical significance. In all studies, the experimental group was compared with its specific time control group.

\section{Results}

There was no perceivable change in the serum calcium level in group A fishes throughout the experiment. The serum calcium level of microcystin-LR injected Heteropneustes fossilis (group B) showed no change up to day 5 . The level exhibited a decrease from day 10 to day 30 (close of experiment). In microcystin-LR injected fish kept in $\mathrm{ZnCl}_{2}$ (group C), the serum calcium level showed no perceivable change throughout the experiment. In group $\mathrm{D}$ fishes kept in $\mathrm{ZnCl}_{2}$ no change in serum calcium level was observed throughout the experiment (Fig. 1).

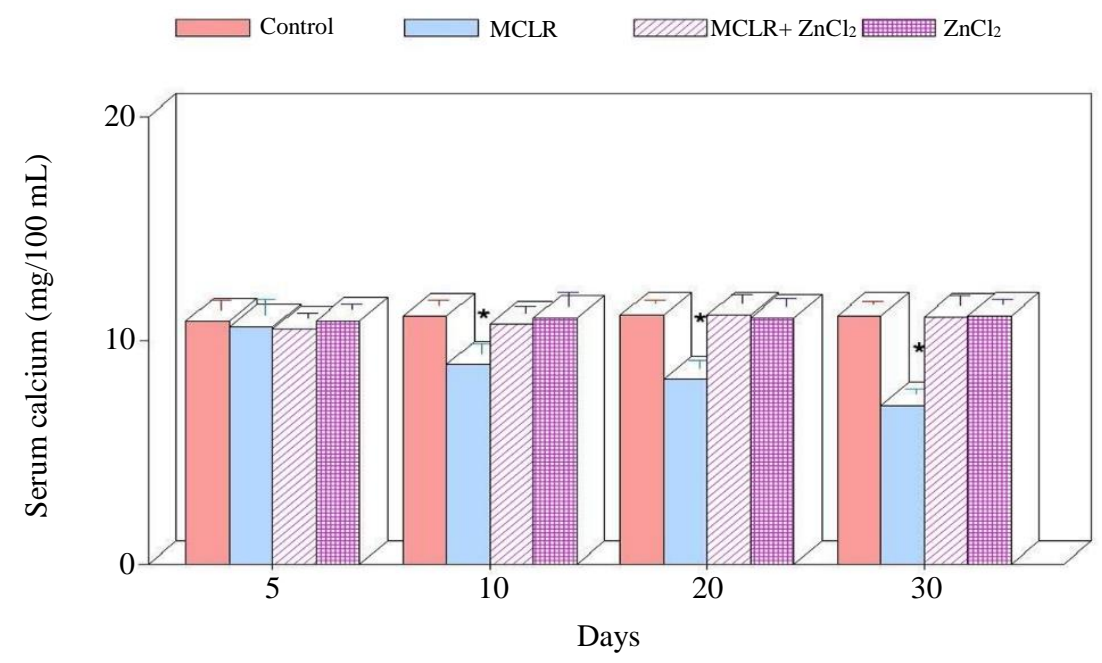

Fig. 1: Serum calcium levels of saline or microcystin treated Heteropneustes fossils kept either in freshwater or kept in water containing $\mathrm{ZnCl}_{2}$. Values are mean \pm S.E. of six specimens. Asterisk indicates significant differences $(\mathrm{P}<0.05)$ from control 
Ultimobranchial gland of vehicle treated Heteropneustes fossilis (group A; Fig. 2) is similar in the histological structure as described earlier for control fish (Prakash et al., 2016). There was no change in histological architecture of UBG cell throughout the experiment. In microcystin-LR treated fish (group B) the nuclear volume of UBG cell exhibits no change up to day 5. Thereafter the nuclear volume exhibits a progressive decrease from day 10 to day 30 (Fig. 3). On day 10 and day 20 degeneration of ultimobranchial cells sets in (Fig. 4). Extremely degenerated cells were observed on day 30 (Fig. 5).

In group $\mathrm{C}$ fishes (MCLR injected and kept in $\mathrm{ZnCl}_{2}$ ) histological structure and the nuclear volume of UBG cells exhibit almost no change throughout the experiment. The nuclear volume and histological structure of UBG cells of group D fish were similar to control fish (group A).

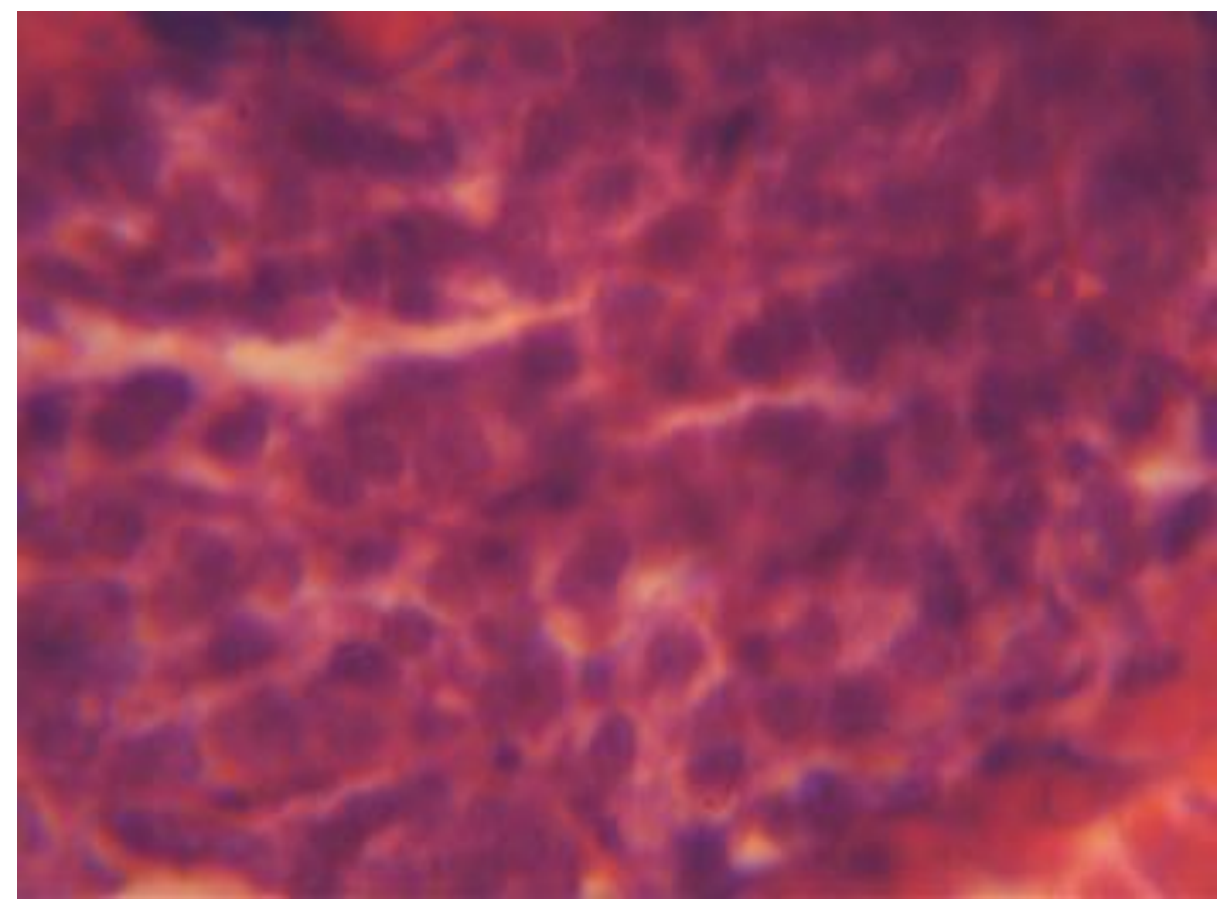

Fig. 2: Ultimobranchial gland of control Heteropneustes fossilis exhibiting follicles and cell cords (broken arrow). HE X 200

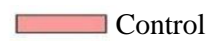

$\square$ MCLR

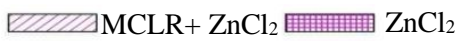

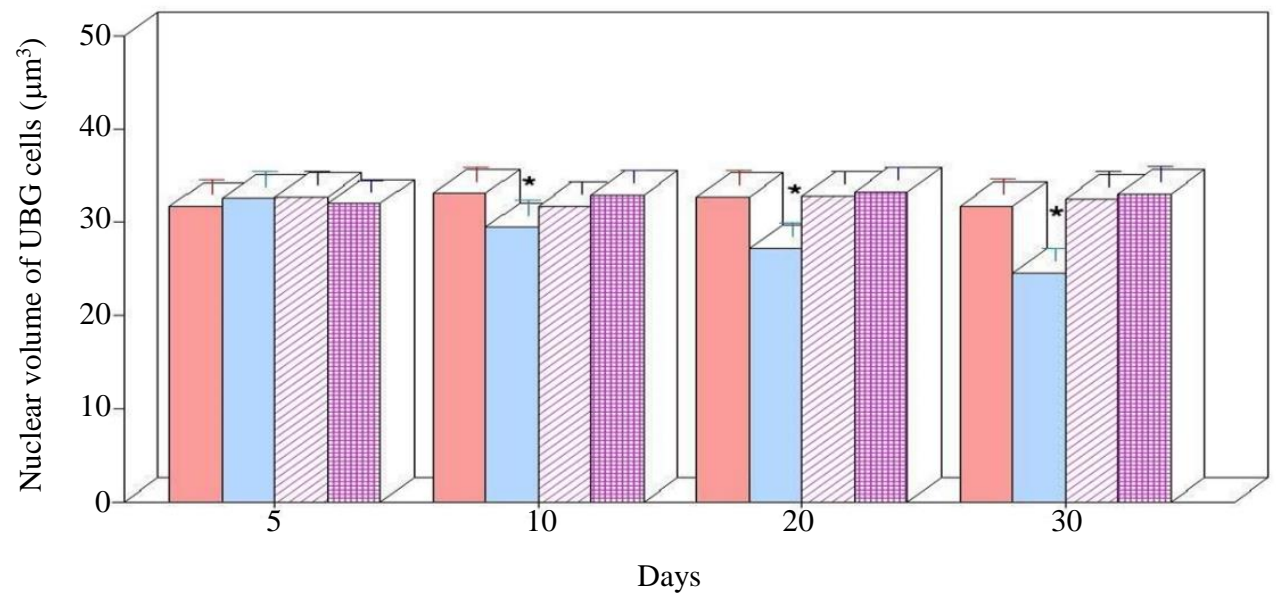

Fig. 3: Nuclear volume of ultimobranchial cells of saline or microcystin treated Heteropneustes fossils kept either in freshwater or kept in water containing $\mathrm{ZnCl}_{2}$. Values are mean $\pm \mathrm{SE}$ of six specimens. Asterisk indicates significant differences $(\mathrm{P}<0.05)$ from control group 


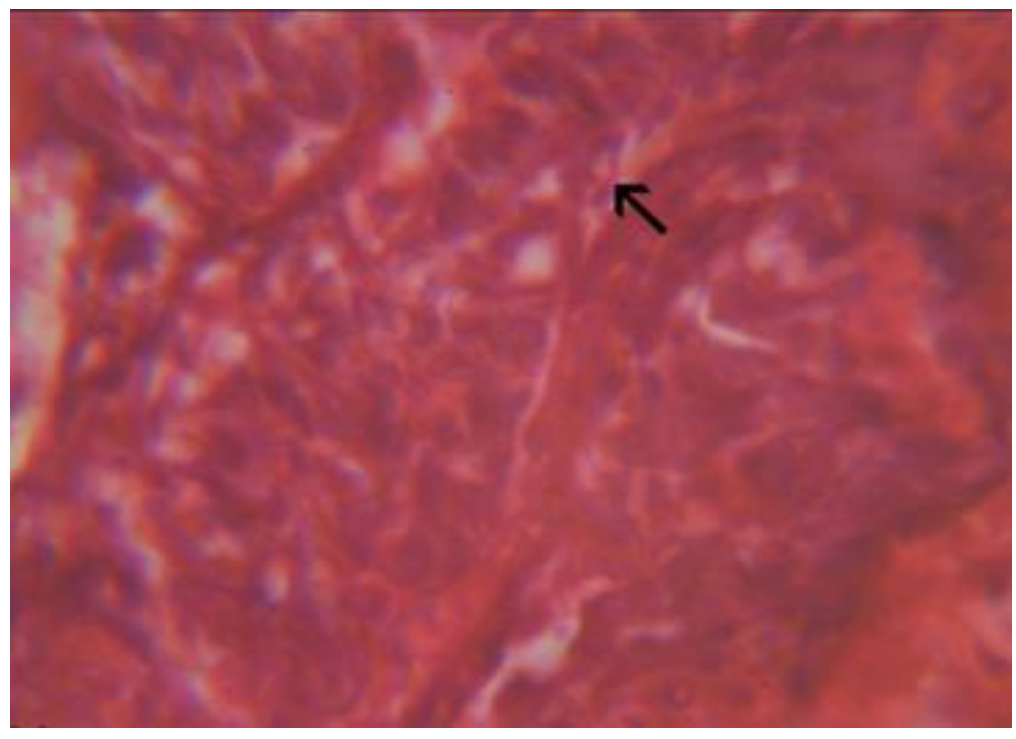

Fig. 4: Ultimobranchial gland of 20 days microcystin treated Heteropneustes fossils kept in freshwater exhibiting degeneration (arrow). HE X 500

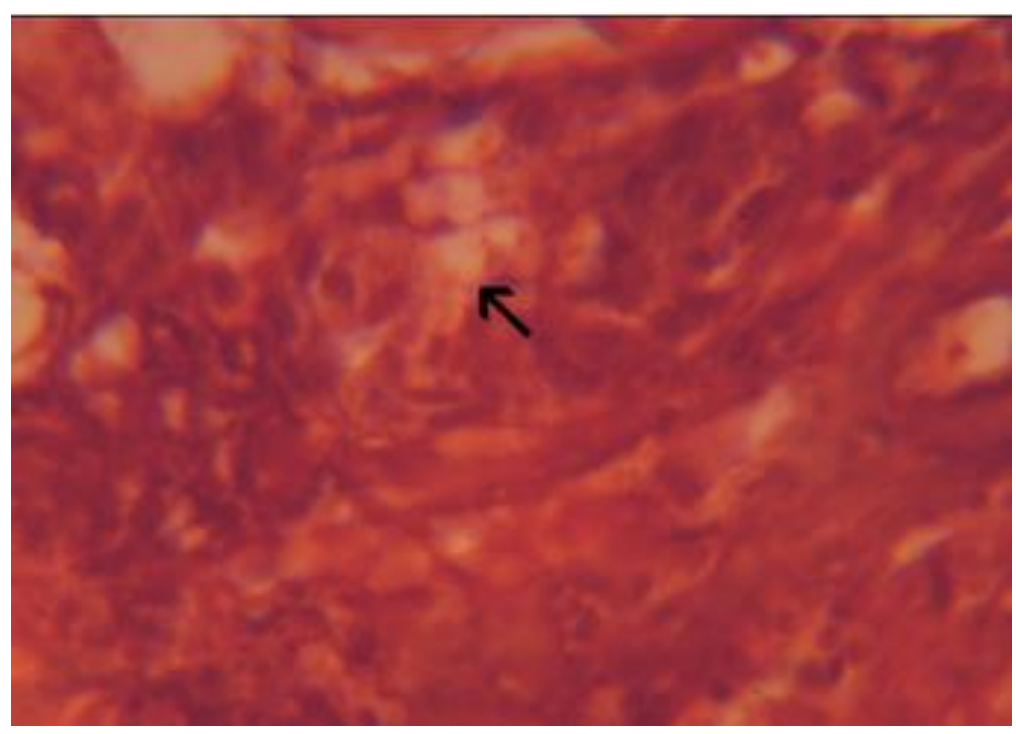

Fig. 5: Ultimobranchial gland of 30 days microcystin treated Heteropneustes fossils kept in freshwater exhibiting extremely degeneration (arrow). HE X 500

\section{Discussion}

In the present study the nuclear volume of UBG exhibited a progressive decrease from day 10 to day 30 . Moreover, the UBG cells show degeneration from day 10 to day 30. The inactivity of UBG could be explained on the basis of prolonged hypocalcemia caused by MCLR treatment. Earlier to the present study, there exists no study regarding the effect of Microcystin on the fish UBG. The observed inactivity and degeneration of UBG in treated fish derives support from the similar observations reported by other investigators after exposure of the fish to different toxicants-deltamethrin (Srivastav et al., 2002), metacid (Mishra et al., 2004), cypermethrin (Mishra et al., 2005), cadmium (Rai et al., 2009), botanical pesticide (Prasad et al., 2011a; 2011b; Kumar et al., 2013) and mercury (Agarwal, 2013). Inactivity with prominent degenerating changes in UBG cells were reported by (Srivastav et al., 2019) in frog Euphlyctis cyanophlyctis. The foregoing study is also in conformity with the earlier reports on the UBG in which hypoactivity/inactivity of the gland has been reported 
in response to calcitonin induced hypocalcemia in the fish-Anguilla anguilla (Peignoux-Deville et al., 1975), Gasterosteus aculeatus (Bonga, 1980), Clarias batrachus (Srivastav et al., 1989), Amphipnous cuchia (Tiwari, 1993) and Heteropneustes fossilis (Srivastav et al., 2009). Prolonged hypocalcemia caused by microcystin exposure provoked continuous disuse of the ultimobranchial gland resulting into degeneration and vacuolization of the gland. $\mathrm{ZnCl}_{2}$ has been reported to be protective against MC-LR toxicity on blood calcium and phosphate level of Heteropneustes fossilis (Prakash et al., 2016).

\section{Conclusion}

We conclude that microcystin-LR exposure to fish Heteropneustes fossilis alters the blood electrolyte (calcium) inducing hypocalcemia. Microcystin-LR all showed degenerative changes in ultimobranchial gland. When $\mathrm{ZnCl}_{2}$ was added to media containing the fish calcium level showed recovery and ultimobranchial gland was not affected, indicating $\mathrm{Zn}^{++}$acted as protective agent against microcystin-LR toxicity.

\section{Acknowledgment}

We are thankful to University Grants Commission, New Delhi for providing financial assistance [RGNF No. F.14-2(SC)/2010 (SA-III)] for this study.

\section{Author's Contributions}

Chandra Prakash: Conduct of experiment, formal analysis and investigation; methodology, funding acquisition.

Sunil Kumar: Supervision, writing, original draft preparation.

\section{Ethics}

Animal handling and sacrifice were carried out following the guidelines provided by Ethics Committee of the DDU Gorakhpur University.

\section{Reference}

Agarwal, K. (2013). Heavy metals: Impact on fish calcium regulation (Doctoral dissertation, Ph. D. Thesis, University of Gorakhpur, Gorakhpur, India).

Carmichael, W. W. (1992). Cyanobacteria secondary metabolites-the cyanotoxins. Journal of Applied Bacteriology, 72(6), 445-459.

https://doi.org/10.1111/j.1365-2672.1992.tb01858.x

Carmichael, W. W. (1994). The toxins of cyanobacteria. Scientific American, 270(1), 78-86 https://doi.org/10.1038/scientificamerican0194-78
Carmichael, W. W. (2001). Health effects of toxinproducing cyanobacteria: "The CyanoHABs". Human and ecological risk assessment: An International Journal, 7(5), 1393-1407. https://doi.org/10.1080/20018091095087

Chorus, I. (2001). Introduction: cyanotoxins-research for environmental safety and human health. In Cyanotoxins (pp. 1-4). Springer, Berlin, Heidelberg. https://doi.org/10.1007/978-3-642-59514-1_1

Codd, G., Bell, S., Kaya, K., Ward, C., Beattie, K., \& Metcalf, J. (1999). Cyanobacterial toxins, exposure routes and human health. European Journal of Phycology, 34(4), 405-415. https://doi.org/10.1080/09670269910001736462

Codd, G. A., Lindsay, J., Young, F. M., Morrison, L. F., \& Metcalf, J. S. (2005). Harmful cyanobacteria. In Harmful cyanobacteria (pp. 1-23). Springer, Dordrecht. https://doi.org/10.1007/1-4020-3022-3_1

Francis, G. (1878). Poisonous australian lake. Nature, 18(444), 11-12. https://doi.org/10.1038/018011d0

Kumar, A., Prasad, M., Suzuki, N., Srivastav, S. K., \& Srivastav, A. K. (2013). Influence of a botanical pesticide, azadirachtin, on ultimobranchial gland of the freshwater catfish Heteropneustes fossilis. Toxicological \& Environmental Chemistry, 95(10), 1702-1711. https://doi.org/10.1080/02772248.2014.895365

Kumar, B., \& Sinha, A. (2014). Microcystis toxic blooms in fish culture ponds and their biological and chemical control. International Journal of Scientific \& Technology Research, 3(3), 398-410. https://www.ijstr.org/final-print/mar2014/MicrocystisToxic-Blooms-In-Fish-Culture-Ponds-And-TheirBiological-And-Chemical-Control.pdf

Mishra, D., Srivastav, S. K., \& Srivastav, A. K. (2004). Plasma calcium and inorganic phosphate levels of a teleost Heteropneustes fossilis exposed to metacid-50. Malaysian Applied Biology, 33(2), 19-25. https://www.researchgate.net/publication/28128947 7_Plasma_calcium_and_inorganic_phosphate_levels _of_a_teleost_Heteropneustes_fossilis_exposed_to_ metacid-50

Mishra, D., Srivastav, S. K., \& Srivastav, A. K. (2005). Effects of the insecticide cypermethrin on plasma calcium and ultimobranchial gland of a teleost, Heteropneustes fossilis. Ecotoxicology and Environmental Safety, 60(2), 193-197. https://doi.org/10.1016/j.ecoenv.2003.12.020

Nasri, A. B., Bouaïcha, N., \& Fastner, J. (2004). First report of a microcystin-containing bloom of the cyanobacteria Microcystis spp. in lake Oubeira, Eastern Algeria. Archives of Environmental Contamination and Toxicology, 46(2), 197-202. https://doi.org/10.1007/s00244-003-2283-7 
Peignoux-Deville, J., Lopez, E., Lallier, F., MartellyBagot, E., \& Milet, C. (1975). Responses of the ultimobranchial body in eels (Anguilla anguilla L.) maintained in sea water and experimentally matured, to injections of synthetic salmon calcitonin. Cell and Tissue Research, 164(1), 73-83. https://doi.org/10.1007/BF00221696

Prakash, C., Prasad, M., Kumar, A., Mishra, D., Chaudhary, A., \& Srivastav, S. K. (2016). Protective effect of $\mathrm{ZnCl} 2$ on toxicity produced by microcystin-LR on serum calcium and phosphate levels of freshwater catfish Heteropneustes fossilis. International Journal of Pure and Applied Biosciences, 4, 111-117. https://doi.org/10.18782/2320-7051.2166

Prasad, M., Kumar, A., Srivastav, S. K., \& Srivastav, A.K. (2011a).Nerium indicum, a botanical pesticide affects ultimobranchial gland of the catfish Heteropneustes fossilis. Environmental Toxicology, 28(12), 661-665. https://doi.org/10.1002/tox.20744

Prasad, M., Kumar, A., Srivastav, S. K., \& Srivastav, A. K. (2011b). Euphorbia royleana, a botanical pesticide affects ultimobranchial gland of the catfish Heteropneustes fossilis. Egyptian Journal of Biology, 13, 14-20. https://doi.org/10.4314/ejb.v13i1.3

Rai, R., Mishra, D., Srivastav, S. K., \& Srivastav, A. K. (2009). Ultimobranchial gland of a freshwater teleost, Heteropneustes fossilis, in response to cadmium treatment. Environmental Toxicology: An International Journal, 24(6), 589-593. https://doi.org/10.1002/tox.20460

Rao, P. V., Gupta, N., Bhaskar, A. S., \& Jayaraj, R. (2002). Toxins and bioactive compounds from cyanobacteria and their implications on human health. Journal of Environmental Biology, 23(3), 215-224. https://europepmc.org/article/med/12597562

Rogers, E. H., Hunter III, E. S., Moser, V. C., Phillips, P. M., Herkovits, J., Munoz, L., ... \& Chernoff, N. (2005). Potential developmental toxicity of anatoxina, a cyanobacterial toxin. Journal of Applied Toxicology: An International Journal, 25(6), 527-534. https://doi.org/10.1002/jat.1091

Sivonen, K. (1996). Cyanobacterial toxins and toxin production. Phycologia, 35(sup6), 12-24. https://doi.org/10.2216/i0031-8884-35-6S-12.1
Srivastav, A. K., Srivastava, B., Mishra, D., Srivastav, S. K., \& Suzuki, N. (2009). Alterations in the ultimobranchial and parathyroid gland of the garden lizard, Calotes versicolor after prolactin administration. Journal of Biological ResearchThessaloniki, 12(2), 187-192. https://citeseerx.ist.psu.edu/viewdoc/download?doi= 10.1.1.1048.9603\&rep=rep1\&type $=$ pdf

Srivastav, A. K., Srivastava, S. K., Mishra, D., Srivastav, S., \& Srivastav, S. K. (2002). Ultimobranchial gland of freshwater catfish, Heteropneustes fossilis in response to deltamethrin treatment. Bulletin of Environmental Contamination and Toxicology, 68(4), 584-591. https://doi.org/10.1007/s001280294

Srivastav, A. K., Srivastava, S., Srivastav, S. K., Faggio, C., Sekiguchi, T., \& Suzuki, N. (2019). Response of ultimobranchial and parathyroid glands of the Indian skipper frog, Euphlyctis cyanophlyctis to cadmium toxicity. Iranian Journal of Toxicology, 13(3), 39-44. http://ijt.arakmu.ac.ir/browse.php?a_code=A-10-748\&slc_lang=en\&sid $=1$

Srivastav, S. P., Swarup, K., Singh, S., \& Srivastav, A. K. (1989). Effects of calcitonin administration on ultimobranchial gland, stannius corpuscles and prolactin cells in male catfish, clarias-batrachus. Archives of Biology, 100(4), 385-392.

Tiwari, P. R. (1993). Endocrinal regulation of calcium in teleost. PhD diss., University of Gorakhpur.

Tyagi, M. B., Thakur, J. K., Singh, D. P., Kumar, A., Prasuna, E. G., \& Kumar, A. (1999). Cyanobacterial toxins: the current status. Journal of Microbiology and Biotechnology, 9(1), 9-21. https://www.koreascience.or.kr/article/JAKO199911 922242648.page

Bonga, S. W. (1980). Effect of synthetic salmon calcitonin and low ambient calcium on plasma calcium, ultimobranchial cells, Stannius bodies and prolactin cells in the teleost Gasterosteus aculeatus. General and Comparative Endocrinology, 40(1), 99-108. https://doi.org/10.1016/0016-6480(80)90100-8

Wiegand, C., \& Pflugmacher, S. (2005). Ecotoxicological effects of selected cyanobacterial secondary metabolites a short review. Toxicology and Applied Pharmacology, 203(3), 201-218. https://doi.org/10.1016/j.taap.2004.11.002 